\title{
RESET
}

Recherches en sciences sociales sur Internet

6 | 2017

Patrimoine et patrimonialisation numériques

\section{Legal Implications of Digital Heritagization}

Implications juridiques de la patrimonialisation numérique

\section{Rolf H. Weber and Lennart Chrobak}

\section{(2) OpenEdition}

\section{Journals}

Electronic version

URL: http://journals.openedition.org/reset/826

DOI: $10.4000 /$ reset.826

ISSN: 2264-6221

\section{Publisher}

Association Recherches en sciences sociales sur Internet

\section{Electronic reference}

Rolf $\mathrm{H}$. Weber and Lennart Chrobak, «Legal Implications of Digital Heritagization », RESET [Online], 6 | 2017, Online since 30 October 2016, connection on 19 April 2019. URL : http:// journals.openedition.org/reset/826 ; DOI : 10.4000/reset.826

This text was automatically generated on 19 April 2019

(c) Association Recherches en sciences sociales sur Internet 


\section{Legal Implications of Digital Heritagization}

Implications juridiques de la patrimonialisation numérique

Rolf H. Weber and Lennart Chrobak

\section{Introduction}

1 The concept of digital heritage denotes a new form of legacy in the changing digital environment. This rather abstract term originates from the UNESCO Charter on the Preservation of Digital Heritage (2003), aiming at conserving and protecting digital equivalents of "the world's heritage of books, works of art and monuments of history and science" (UNESCO, Preamble; Cf. Sheppard, 2012: 2). In terms of content, it comprises both digitized and "born digital" materials of enduring value, such as cultural, educational, scientific and administrative resources as well as technical, legal, medical or other kinds of information, whose public accessibility should be preserved for future generations ${ }^{2}$. Thereby, the charter seeks to keep a fair balance between the creator's rights and the interest of the public to access these resources ${ }^{3}$.

2 Heritage institutions, such as public libraries, archives or museums - but also private undertakings - fulfil a predominant role with regard to the acquisition, storage, dissemination and use of information and knowledge (Fischman Afori, 2013: 392 et seq.); these intermediaries provide public access to cultural and scientific content which forms a vital basis for the information society and serves as a catalyst for academic research and economy. ${ }^{4}$

3 Against the background of the ongoing digital evolution and the related increase of data, there is a growing conviction on the national as well as international level that digital preservation strategies for analogue and electronic resources have to be actively elaborated ${ }^{5}$. Thus, memory institutions participating in these processes do not only guard analogue collections, but also become involved in the creation of new digital 
environments serving as a gateway to information and services in the digital society (Purday, 2010: 176.).

4 However, digital heritagization is not only a relevant societal phenomenon, but it also gains significance in terms of intellectual property law. Since the digitization of analogue resources and the processing of born digital content presuppose inter alia the reproduction and duplication of the content in question, the field of copyright law is of particular interest. Thereby, the discussion on the national and international level is characterized by the heterogeneous and partly restrictive legal framework. On the one hand, this fact inevitably raises general questions with regard to the rights holder as well as the extent and transfer of rights. On the other hand, specific issues such as orphan works, change of format, digitization of whole collections or Digital Rights Management schemes have to be considered in this context. In addition the issue has been raised as to whether the law keeps pace with recent technological developments. This contribution takes the given situation as an impetus to shed light on the legal implications of digital heritagization, considering the theoretical legal framework as well as selected national and international judgments rendered in civil and common law jurisdictions.

\section{Digital Heritagization: a multi-stakeholder process}

Digital heritagization as a compound term refers to the processes through which heritage is created in digital environments by means of $\mathrm{ICT}^{6}$. These processes encompass both "born digital" content directly generated by means of ICT devices and digitized analogue resources, the particular focus of this article.

Various heritage institutions initiated mass-scale digitization projects aiming at preserving valuable and significant analogue resources in digital format ${ }^{7}$. In the meantime, there are national as well as international efforts seeking to create comprehensive digital collections based on the model of the famous Alexandrian Library (Fischman Afori, 2013: 397). The most prominent example, concerning the field of literary heritage, is the European Union's Europeana project (Fischman Afori, 2013: 397), but besides it, notable initiatives are also taken at the national level, e.g. in Switzerland ${ }^{8}$, seeking to safeguard valuable information by means of digital technology (Fischman Afori, 2013: 397). The Europeana project's focus is, on the one hand, on old and valuable works, such as antiquarian books or rare handwritings, whose accessibility would otherwise be limited, and, on the other hand, on highly frequented contemporary works, such as scientific literature or journals, that are made available to the public in order to contribute to educational or scientific purposes. However, the digitization and public dissemination of these works is not governed by a direct contractual relationship between the heritage institutions disposing of the content and the rights holder legally entitled to the work (Fischman Afori, 2013: 393).

7 Furthermore, private undertakings fulfil a considerable role for purposes of digital heritagization. In this context, particular reference has to be made to the mass-scale digitization initiated by Google in cooperation with American libraries, commonly known as "Google Books", in the course of which millions of books were digitized and made available online. This comprehensive searchable literature database provides full access to content in the public domain, in contrast to copyrighted works being only partially retrievable (Häyrinen, 2012: 59; Fischman Afori, 2013: 397)9. 
Conceptually, the previously mentioned resources have to be distinguished from "born digital" resources. Recent literary works and scientific articles, in particular, may be published in analogue as well as in digital form, or even exclusively in digital form. Since contemporary content is and will be primarily produced in digital form, this area deserves closer attention in the future. In this regard, the developments in the field of egovernment and the increasing digitization of "grey literature", such as official reports, policy statements or legislative documents which were previously difficult to access, are also worth mentioning and raise questions in terms of preservation.

9 Regarding "born digital heritage", its accessibility is generally subject to a contract through which the rights holder confers an online license to the providing public memory institution (Fischman Afori, 2013: 393). It should be pointed out, however, that this is not always the case: the Portuguese Web archive, for example, proceeds to the act of archiving with no prior third-party request, but withdraws content upon request or if it poses legal challenges (e.g., paedophile content) ${ }^{10}$.

More broadly, and perhaps more prominently due to its global reach, online archiving projects with a global focus, e.g. Internet Archive, became key players for purposes of digital heritagization and aim to preserve content such as web sites, software, movies, music and other types of information on a long term basis, with the purpose of providing free access to these resources for interested researchers as well as other users. ${ }^{11}$

11 In order to avoid "digital black holes", i.e. digitized or born digital information contained in digital environments that are no longer maintained or technically not accessible anymore, due to obsolete formats or technology, steps are also taken to make these contents a part of our collective memory, such as Twitter feeds or even whole websites, retrievable for future generations. ${ }^{12}$ However, the question of the preservation and accessibility of the abovementioned born digital or digitized content is twofold: on the one hand, the content itself has to be digitally preserved in order to remain accessible; on the other hand, the access itself, i.e. the underlying hardware and software have to be secured, because the stored data cannot be decrypted without the corresponding technological device. Archaic formats like the floppy disk, audio tapes and CDs already illustrate the problems that could be faced in the future (Dartnell, 2015: 2).

\section{Legal Implications}

\section{General legal framework}

12 The abovementioned processes of digital heritagization entail a challenging interdisciplinary discourse, involving social, political, and economic dimensions as well as the technical issues of implementation. However, the legal aspects often prove to be the key topics for the discussion. The legal implications of digital heritagization, particularly the admissibility of copying and distributing content, are located in the field of copyright law. In order to comprehensively approach the relevant legal sources, national as well as international legislations have to be taken into account constituting a multi-layered framework.

13 On the international level, general principles have been incorporated by the WTO Agreement on Trade-Related Aspects of Intellectual Property Rights (TRIPs), the Berne Convention for the Protection of Literary and Artistic Works and the WIPO Copyright Treaty. Furthermore, 
supranational EU legislation harmonizing selected legal aspects has to be considered; thereby, the Directive 2001/29/EC (InfoSoc Directive) constitutes the most influential piece of secondary legislation in the digital context (Kuhlen, 2013: 2; Gowers, 2006: 32; European Commission, 2008: 5). Since the genuine legislative competence remained at State level (Kuhlen, 2013: 1), the national transposing legislation in conjunction with the complementary national provisions has also to be considered.

In order to protect the intellectual work of individuals, copyright law confers certain exclusive rights to the author, of which he can dispose within the limits set by law. Thus, it is for him to decide about the direct as well as derivative use of his intellectual creation, such as the right of reproduction, publication or distribution (Dnes, 2013: 420; Kuhlen, 2013: 2). However, as an expression of a fair and careful balance between public interests and private proprietary rights, the latter can be limited under certain conditions (Fischman Afori, 2013: 401; Müller \& Oertli, 2006: Art. 19 N 4; Kuhlen, 2013: 3). Depending on the "legal family"13, the limitations, enabling certain persons or institutions to make use of protected works, are differently conceived (Müller \& Oertli, 2006: Art. 19 N 20). In this regard, the so called "three-step test" ${ }^{14}$ incorporated in Art. 9(2) Berne Convention, Art. 13 TRIPs, and Art. 10 WCT imposes an internationally acknowledged minimal standard according to which (1) the exceptions should be constrained to certain special cases, (2) they should not conflict with the normal exploitation of the work, and (3) they should not unreasonably prejudice the legitimate interests of the author or rights holder (Kuhlen, 2013: 13 et seq.; Fischman Afori, 2013: 401) ${ }^{15}$. As a consequence of this broad formulation, the approaches of the legal families towards limitations may significantly differ.

16 While the continental European legal families, including inter alia Switzerland as part of the Germanic legal tradition, refer to codified legal exemptions that enumerate admissible forms of free use, the common law systems adhere to the doctrine of "fair use" or "fair dealing" (Müller \& Oertli, 2006: Art. 19 N 20 et seq.). On the basis of (semi)open norms providing general guidelines for their application (Fischman Afori, 2013: 401), certain forms of use of copyrighted materials can become judicially admissible without obtaining previous permission of the rights holder (Häyrinen, 2012: 60). However, from a conceptual point of view these limitations of authors' rights rather resemble ex-post defenses to copyright infringement actions than ex-ante legal exceptions (Dnes, 2013: 423 et seq., 431).

17 The assessment of fair use regarding copyrighted content is primarily based on four nonexclusive factors laid down in 17 U.S.C. $\$ 107$, but courts may also consider additional elements (Dnes, 2013: 432), indicating a conceptual proximity to the principle of equity (Dnes, 2013: 424). Due to its reference to certain prescribed purposes, the scope of application of the fair dealings doctrine contained in the UK Copyright, Designs and Patents Act 1988 is narrowed down and thereby approximates the legal exceptions of the continental legal orders, which is to a certain degree attributable to the influence of EU case law and secondary legislation (Dnes, 2013: 423 et seq.). However, both approaches constitute flexible solutions and may easily adapt to new technological developments (Dnes, 2013: 419).

18 With regard to limitations of author's rights, the continental civil law systems are strongly influenced by the mentioned InfoSoc Directive. Its second chapter imposes maximum harmonization measures and provides both exhaustive mandatory exceptions 
(Art. 5[1]) and optional limitations (Art. 5[2]-[4]) (Foundation for Information Policy Research, 2003: 14 et seq). Besides the exceptions that have to be transposed, national legislators are free to decide which implementations they undertake, but they may not introduce additional exceptions. However, copyright law in Europe still significantly differs among countries and rather constitutes a patchwork of national rules than a harmonized field of law (European Commission, 2008: 5). Equally, the approach and implementation of exceptions to authors' rights deviates depending on the legal order and already became subject to court proceedings.

\section{Legal challenges}

In light of the complex legal framework mentioned above, heritage institutions involved in the process of digital heritagization and related mass-scale digitization projects are confronted with different problems in terms of copyright law. Two issues are of particular interest in this regard: on the one hand, the legal appreciation of digital copies of analogue works and, on the other hand, the admissibility of the online deployment of the digitized content and related services.

As an expression of the exclusive rights conferred by copyright law, in general it is for the rights holder to authorize any form of reproduction as well as any communication of its work to the public according to Art. 2, 3 InfoSoc Directive. ${ }^{16}$ As stated, there are limited exceptions to these rights granted to public heritage institutions, such as in Art. 5(2)(c), (3)(n) InfoSoc Directive, allowing certain forms of use of the copyrighted works. ${ }^{17}$ In view of the wording adopted, several issues remain, however, undetermined. Hence, it is still questionable whether, and if yes how many, digital copies, requiring a change of format and eventually affecting the author's exclusive rights, may be created..$^{18}$ Moreover, it has to be assessed as to whether whole works or even whole collections may be digitized. ${ }^{19}$

In terms of content, heritage institutions are concerned with different kinds of works. Besides the previously mentioned legal problems related to copyrighted works, massscale digitization projects also involve public domain material or content that is no longer published (so called out-of-print works) ${ }^{20}$, but in particular orphan works (Art. 2(1) Orphan Works Directive). There is a high percentage of cultural and scientific resources contained in the collections of memory institutions whose right holders cannot be identified or located; due to the term of copyright protection, serious impediments for digitization projects might accrue since the owner's consent is difficult or even impossible to obtain (Fischman Afori, 2013: 396).

Apart from the previously mentioned analogue works which are not subject to a contractual relationship between rights holder and source provider, the discourse of digital heritagization also involves born digital content regularly subject to a license agreement. Public institutions, such as libraries or archives, that would like to make use of the respective electronic resources, e.g. e-books or e-journals, have to comply with the license terms that however tend to exceed the exclusive rights conferred by copyright law at the expense of heritage institutions and end users, respectively (Fischman Afori, 2013: 393, 395). If works are published in analogue and (subsequently) in digital form, the legal implications remain undetermined to a certain extent and frictions are not inconceivable. 


\section{Case law} copyright law became subject to proceedings before national as well as international courts. Subsequently, some of the important judgments rendered by the European Court of Justice (ECJ), the Swiss Federal Tribunal (SFT) and the United States District Court for the Southern District of New York (S.D.N.Y.) with regard to digitization processes and related issues will be discussed and analyzed, taking into account a comparative legal perspective in order to point out the deviating approaches of the two main legal families.

\section{ECJ Case-117/13 Technische Universität Darmstadt v Eugen Ulmer KG}

The case decided by the ECJ in the course of a preliminary ruling procedure involved different aspects of interest for purposes of digital heritagization. At the origin of the proceedings is an action filed before the German Federal Supreme Court by Eugen Ulmer $\mathrm{KG}^{21}$ against Technische Universität Darmstadt, which maintains a public library with electronic workstations allowing to digitally access specific books contained in its collection. The subject of the dispute was the digitization of a copyrighted scientific book which the TU Darmstadt made publicly available through these dedicated terminals. Thus, the library users were able to read and print out the book or acquire a digital copy. The publisher's offer to provide the copyrighted resource as e-book, subject to a license agreement, was refused by TU Darmstadt. ${ }^{22}$

The case involved the application of $\S 52 \mathrm{~b}$ German Copyright Act (GCA), constituting the national transposition of Art. 5(3)(n) InfoSoc Directive, and thus required the interpretation of EU law. Accordingly, the German Federal Supreme Court suspended its proceedings and referred three preliminary questions to the ECJ: 1) Does the limitation of $\S 52 \mathrm{~b} \mathrm{GCA}$ also apply if the work in question is available in digital form and offered to the library for utilization subject to a license agreement; 2 ) is the library allowed to digitize a work in its collection in order to make it accessible to the public by means of dedicated terminals, and 3) are the users entitled to print out these works or save them on a USBstick? ${ }^{23}$

In its deliberations, the ECJ mainly followed the opinion of Advocate General Jääskinen and declared the digitization of works admissible without prior consent of the rights holder, if necessary to provide access to the public by dedicated terminals. Even though, Art. 5(3)(n) InfoSoc Directive would primarily relate to the exclusive right of communication pursuant to Art. 3 InfoSoc Directive ${ }^{24}$, the ECJ acknowledged an ancillary right of reproduction in this regard and declared the accompanying digitization of the works admissible, because the "right" of these establishments, derived from the limitation, could be otherwise rendered meaningless or ineffective. ${ }^{25}$ However, since this right would only comprise "specific acts of reproduction" pursuant to Art. 5(2)(c) InfoSoc Directive $^{26}$, the substantial scope of the limitation would encompass the digitization of certain, single works, but not whole collections. ${ }^{27}$ This assessment would also be in compliance with the conditions set by the "three-step test" in Art. 5(5) InfoSoc Directive. ${ }^{28}$ Against the background of the first preliminary question ${ }^{29}$, the Court further specified, that the exception of Art. 5(3)(n) InfoSoc Directive would even remain applicable in case that an electronic version of the book is offered to the library in accordance with the 
publisher's license terms, since the reservation "purchase or licensing terms" would refer to contractual terms actually agreed, but not to unilateral contractual offers. ${ }^{30}$

The subsequent and more interesting question ${ }^{31}$, as to whether copyright protected content made accessible by electronic workstations in the library may be printed out or saved on a USB stick was, however, denied by the judges in Luxembourg. The creation of analogue and digital copies does not affect the right of communication, but constitutes supplementary acts of reproduction outside the scope of Art. 5(3)(n) InfoSoc Directive. ${ }^{32}$ But, according to the ECJ, paper printouts could be comprised by the exceptions of Art. 5 $(2)(a, b)$ InfoSoc Directive ${ }^{33}$; thereby, the extent of copies may not violate the interest of the right holder. ${ }^{34}$

The ECJ was asked to interpret the InfoSoc Directive, which aims at harmonizing certain aspects of copyright law in the information society, but remained unable to adapt to recent technological challenges in the digital context. ${ }^{35}$ Under European law, heritage institutions may digitize copyrighted content, because Art. 5(3)(n) in conjunction with Art. 5(2)(c) InfoSoc Directive confers to them an "ancillary right" of digitization with regard to old, valuable resources or highly frequented content..$^{36}$ Thereby, the scope of this right has been further extended to the detriment of publishers (Peifer, 2015: 365446), since the digitization of analogue resources, equally available in digital format, is in compliance with the exception as long as no licensing agreement on the use of the eresource has been concluded. This is of particular interest with regard to the collections of public heritage institutions, which are composed of analogue and digital resources.

Nonetheless, the impact of the ECJ's judgment should not be overestimated and various questions remained unanswered. First of all, the Directive's personal scope of application is constrained to public institutions and thus the legal appreciation of private digitization initiatives remains unsettled. Secondly, in contrast to the approach of Advocate General Jääskinen who derived the ancillary right of reproduction alternatively from Art. 5(3)(n) or Art. 5(2)(c) InfoSoc Directive ${ }^{37}$, the ECJ read both provisions in conjunction with each other. As a result, digitization processes are in compliance with EU law, however, since the transposition of the exceptions in Art. 5(2) and (3) InfoSoc Directive lies within the discretion of each Member State and EU directives are in general not directly applicable, each national implementation has to be consulted. In the case of Germany, the digitization is not in compliance with copyright law, because $\S 52 \mathrm{~b}$ GCA does not implement Art. 5(2)(c) InfoSoc Directive and the resulting lacuna cannot be filled by means of interpretation (Wiebe \& Müller, 2015: 742; Jani, 2014: 872). Thirdly, the Court held that only certain works of a collection may be digitized and thus the permissibility of mass-scale digitization projects remains questionable in the light of Art. 5(5) and Art. 5(2) (c) InfoSoc Directive. However, since the judgment does not quantify the condition of specificity, the extent to which a collection may be digitized remains unclear. In terms of digital heritagization, the quantitative restrictions raise questions according to which criteria the content to be digitized should be selected. Should only the oldest and most valuable resources or the most frequented books be digitized, excluding cultural diversity in the sense of "small is beautiful"? ${ }^{38}$ Equally, the admissibility of paper printouts has only been superficially analyzed and it remains open as to whether only excerpts or even whole books may be reproduced. ${ }^{39}$

30 Meanwhile, following the preliminary ruling procedure, the German Federal Supreme Court delivered its final judgment ${ }^{40}$, which appears to deviate from the ECJ's findings with regard to subsequent acts of reproduction, such as paper print outs or digital copies on 
usb sticks, and provoked sharp criticism e.g. from the German Publishers and Booksellers Association. ${ }^{41}$

\section{Swiss Federal Tribunal judgment 4A_295/2014}

31 The SFT has recently decided on a related case that was initiated by three scientific publishers - Elsevier, Springer and Thieme - against the Federal Technical University Zurich. The latter maintained a document delivery service in the course of which excerpts of analogue resources within its collection were scanned and provided to the library user by means of analogue or digital copies. ${ }^{42}$ Following the judgment of the Commercial Court of the Canton Zurich, that considered the university's services as inadmissible, because they would not fulfill the notion of "personal use" pursuant to Art. 19 CopA and thus violate the claimants' rights ${ }^{43}$, the SFT approved the appeal of the university.

According to Swiss law, the creation of analogue and digital copies equally affects the author's rights granted by Art. 10 CopA ${ }^{44}$ However, comparable to other civil law systems, the legal exception embedded in Art. 19 CopA allows certain people or institutions to make use of copyright protected content without prior consent.

The SFT was asked to construe and delineate the different forms of "personal use" contained in the provision and thereby clarified the exception's scope of application. In this case, it was contested whether the prohibition to completely reproduce works commercially available according to Art. 19(3)(a) CopA also applies if a third party has been mandated by a private individual entitled to make "personal use" of the copyrighted content. ${ }^{45}$ According to the SFT, the complete reproduction of "works" is solely permitted to private individuals themselves pursuant to Art. 19(1)(a) $\mathrm{CopA}^{46}$, whereas other persons and public institutions enumerated in Art. 19(1)(b,c) CopA may neither perform such processes for themselves nor on behalf of private individuals pursuant to Art. 19(2) CopA. ${ }^{47}$ In line with its previous case law ${ }^{48}$, the SFT held that reproduction processes may take place in analogue as well as digital form. ${ }^{49}$

With regard to the central point of interest (Bieler, 2015: 162), the SFT, in contrast to the deliberations of the court of first instance ${ }^{50}$, interpreted Art. 19(3)(a) CopA, which prohibits the complete reproduction of "works" that served as actual copy template, but not to the single article contained therein, which might also be separately available over an online archive..$^{52}$ The Court ruled in favor of the public's information interest and stated that it would be for the publishers to adapt to the changed needs of the public and to offer scientific articles only in individual format in order to exclude their extensive reproduction in accordance with Art. 19(3)(a) CopA. ${ }^{53}$ Whether the Court's perception is in accordance with the legislator's intention might be questionable. ${ }^{54}$ Moreover, the highest Swiss Court emphasized that public libraries may only produce analogue or digital excerpts on demand, but not on stock, and therefore prohibited the maintenance of a respective online archive. ${ }^{55}$

If, however, a private individual mandates a third person pursuant to Art. 19(2) CopA to produce a (legally permissible) partial reproduction of such a work ${ }^{56}$, the process does not only comprise the creation of analogue or digital copies of resources within the library's collection, but may also involve their subsequent delivery by post or email. ${ }^{57}$ In this regard, the SFT confirmed that the document delivery service maintained by the university is in line with Art. 19(2) CopA and does not constitute a relevant form of use in 
terms of copyright law according to Art. 10(1)(b,c) CopA..$^{58}$ A deviating opinion of the Swiss legislator due to the emergence of digital technology could not be ascertained. ${ }^{59}$

The SFT's judgment provides valuable insights for purposes of digital heritagization. In line with the Court's comprehensive technology-neutral conception of the Swiss CopA ${ }^{60}$, digitization processes are considered as being in compliance with the legal exception of Art. 19 CopA. The complete reproduction of analogue, commercially available works is, however, limited to private individuals; public heritage institutions may neither completely copy such resources in their own interest, e.g. for preservation purposes, nor those of third parties.

Besides that, the Court substantiated the notion of "work" underlying the prohibition of Art. 19(3)(a) CopA and thus further clarified the provision's scope of application. The quantification in case that the resource in question is not divided into single articles remains, however, open. Furthermore, the Court declared partial reproductions, e.g. of highly frequented works, on behalf of private individuals admissible and such excerpts may also be provided in analogue or digital form by means of a document delivery service. Aiming at fostering the information interest of society and science, the SFT construed the Swiss CopA and its legal exceptions in the light of the ongoing technological developments and enabled users to make comprehensive use of new digital technologies (Bieler, 2015: 163 et seq). Since the SFT, however, excluded the preventive creation and storage of digital copies by public heritage institutions in order to maintain an online archive, the judgment can be considered as a damper on public mass-scale digitization projects. Though the restriction imposed by the judges involves "only" copyright protected content, public collections often comprise orphan works and thus public mass-scale digitization projects and other online services will not be feasible unless they refer to content in the public domain or with regard to which an online license has been acquired.

\section{The Authors Guild, Inc. v. Google, Inc., No. 05 CV 8136 (S.D.N.Y.)}

The case before the S.D.N.Y. involved the private mass-digitization project initiated by Google in cooperation with public and private American libraries, comprising both inprint and out-of-print resources. ${ }^{61}$ The initiators thereby digitally reproduced and stored millions of books by means of digital copies on their servers aiming to make those works publicly available. ${ }^{62}$ While public domain content became completely retrievable, copyright protected books were provided only to a limited extent in form of "snippets". ${ }^{63}$ In the course of the subsequent dispute between the Authors Guild, representing the interest of published authors, and Google, a settlement agreement was primarily negotiated, which was, however, not judicially confirmed. ${ }^{64}$ Following this, the Authors Guild issued a claim of copyright infringement against Google which relied on the defense of fair use according to 17 U.S.C. $\$ 107 .{ }^{65}$ In the light of the doctrine's general aim to "fulfill copyright's very purpose, "[t]o promote the Progress of Science and useful Arts"”66 and by reference to the four factors laid down in 17 U.S.C. $\$ 107(1)-(4)$, the S.D.N.Y. was asked to analyze as to whether the actions performed by Google fall within the scope of fair use under copyright law (Xalabarder, 2014: 55).

With regard to the first factor, namely the purpose and character of the use ${ }^{67}$, the Court considered the use of copyrighted resources by Google Books to be "highly transformative". ${ }^{68}$ First of all, the digitization of analogue text and its subsequent display 
by means of snippets would facilitate searching and finding books. ${ }^{69}$ Furthermore, the transformation of analogue text into digital data would support new forms of research, such as data mining and text mining. ${ }^{70}$ Accordingly, Google uses words for a different purpose or in a way they have not been used before and thus "adds value to the original". ${ }^{71}$ Even though the use in a commercial way "tends to weigh against the finding of fair use"72 and Google obviously gained, at least indirectly, commercial benefits, this finding was outweighed, on the one hand, by the fact that Google was not engaged in the direct commercialization of the works by selling the digital scans or snippets and, on the other hand, by the public interest in the project. ${ }^{73}$

The consideration with regard to the second factor, namely the nature of the copyrighted works ${ }^{74}$, further fostered a finding of fair use, since the project predominantly involved non-fictional books available to the public ${ }^{75}$, which are less protected in terms of fair use than works of fictional nature (Xalabarder, 2014: 55). The picture slightly changed when the third factor was taken into account, which involved the amount and substantiality of portion used. ${ }^{76}$ The Court held that copying the entirety of a work may still be fair use, but since the full-work reproduction is critical to the functioning of Google Books and only snippets were displayed, the third factor rather tends against a finding of fair use. ${ }^{77}$

With regard to the fourth factor relating to the effect of use upon potential market or value $^{78}$, the Court clearly rejected the plaintiffs' arguments according to which Google Books would serve as a "market replacement" for books and would allow to access entire books. ${ }^{79}$ In contrast, the S.D.N.Y. considered the project as enhancing the sale of books to the benefits of copyright holders, because the works in question could be easily found, and thus strongly favored fair use in this regard. ${ }^{80}$

Weighing the four non-exhaustive factors in the course of an overall assessment, the Court ruled in favor of Google and dismissed the case on grounds of fair use (Xalabarder, 2014: 54). In the Court's opinion, "Google Books provides significant public benefits. It advances the progress of the arts and sciences, while maintaining respectful consideration for the rights of authors and other creative individuals, and without adversely impacting the rights of copyright holders" ${ }^{81}$ It does not only preserve out-ofprint as well as old books and facilitates accessing such resources, but also creates new sources of income for authors and publishers..$^{82}$ Furthermore, the digital reproduction on behalf of the participating libraries was considered as fair use. Google simply provided the technical means to create digital copies of analogue works already owned by the public institutions encouraging lawful uses in accordance with copyright and in other "transformative ways", such as searchable indices of books or preservation. ${ }^{83}$

\section{Comparison}

The judgments point out different legal implications of importance in terms of digital heritagization and illustrate the similar but distinct approaches of the two main legal families in this regard, which are to different extents able to keep pace with the technological developments and changed forms of use of copyrighted content. ${ }^{84}$

On the one hand, due to its broad formulation and its equitable character, the fair use/ fair dealing doctrine implemented in the common law jurisdictions can more easily adapt to technological challenges as well as the needs of the information society and strongly supports processes of digital heritagization. In this respect, there seems to be an assumption that one needs to prevent copyright law from becoming an obstacle to 
cultural developments (Xalabarder, 2014: 56). On the other hand, the Continental European approaches rather favor authors' rights to the public information interest. Accordingly, the S.D.N.Y. rather unsurprisingly confirmed the admissibility of mass-scale digitization projects even by private institutions such as Google, which can serve as incredible tools to advance progress in science and useful arts (Xalabarder, 2014: 56); the Continental European courts, arguing on a technology-neutral basis, confirmed the permissibility of digitization processes to different extents, but refused more extensive initiatives in this context, such as online archives; against the background of the current interpretation of the "three-step test" findings comparable to those of the S.D.N.Y appear rather unlikely for at least the near future (Xalabarder, 2014: 56 et seq).

Subsequently, the question arises whether there is a need to import the fair use doctrine to Continental European jurisdictions and/or to provide for harmonization measures on the European level. Apart from its substantive advantages, the implementation of an equitable "legal transplant", originating from the dual system of common law into civil law jurisdictions is a controversial issue in comparative legal research (Legrand, 1997: 111 et seq.; Örücü, 2002: 205 et seq). Though there have been considerations on the national level to enhance copyrights flexibility by means of the fair use doctrine (Dnes, 2013: 439 et seq), the majority of experts rejects the introduction of such an exception. ${ }^{85}$ Reference to general legal principles known to the civil law family could be a feasible alternative and could serve comparable purposes. This should not obscure the fact that the American doctrine also discusses partial reference to the continental European approach (Lessig, 2008: 267).

Besides, the previously indicated reciprocal relation of advantages and disadvantages of the "fair use" and "closed list" tempt to stereotypically thinking in categories of black and white (Rendas, 2015: 2 et seq, 9). Though, the codified legal exceptions appear to provide a higher degree of legal certainty compared to the common law approach, the ample interpretation of these norms by civil law courts, trying to cope with new technological developments, causes again legal uncertainty and raises questions regarding the separation of powers. ${ }^{86}$ The two allegedly distinct systems thereby resemble each other, because it is finally for the judge to declare a certain behaviour as (in)admissible. Asking which approach is actually more suited to foster the transformation processes of digital heritagization, one could only respond: each in its own way. However, a possible middle course to provide both flexibility and legal certainty could be the reference to categories of uses instead of specific uses. ${ }^{87}$

\section{Conclusions and Recommendations}

Fair and balanced copyright, aiming at advancing the protection and dissemination of cultural heritage in analogue as well as digital form, appears to be one of the major challenges in the evolving information society (Kuhlen, 2013: 16). With regard to digital heritagization, the court judgments previously discussed provide clarification of certain aspects of digital reproduction and new forms of use, but several related issued remain still unsettled.

For example, the legal implications of orphan works constitute one of the pressing issues in this regard, which remained uncovered by the aforementioned judgments notwithstanding their great impact for mass-scale digitization projects. ${ }^{88}$ Heritage institutions "possess" high percentages of these works in their collections and any 
further attempt to extensively digitize copyrighted resources has to address this point (Fischman Afori, 2013: 396). However, in the meantime, the European legislator became active and issued Directive 2012/28/EU ("Orphan Works Directive") which makes orphan works available to the public and provides exceptions and limitations for the use of such works in accordance with the InfoSoc Directive, particularly allowing reproduction for purposes of digitization. ${ }^{89}$

The discourse on the legal implications of digital heritagization illustrates the increased need for a comprehensive global or at least regional solution instead of fragmented optional regimes and "national silos" of copyright legislation. ${ }^{90}$ In this regard, the academic initiative for the creation of a European Copyright Code is worth mentioning, since it tries to carefully weigh public and private interests and provide legal exceptions with enhanced flexibility by reference to a mixture of common law and civil law approaches (Kuhlen, 2013: 16). Of particular interest in this regard is the inclusion of "further limitations" in Art. 5.5 European Copyright Code which would allow new forms of use by analogy based upon the conditions set by the "three-step test". ${ }^{91}$

Moreover, there seems to be a growing conviction on the political level that the European copyright framework needs to be rethought in order to meet the challenges presented by evolving digital markets and environments. According to MEP Julia Reda, rapporteur of the draft report on the evaluation of the InfoSoc Directive published in early $2015^{92}$, copyright rules are not able to cope with the current needs of the information society and complicate the fulfilment of public service obligations by institutions, such as libraries. The technically outdated European legislation with transposition deviations among the Member States constitutes an impediment to cross-border cultural exchange (Clay, 2015). Besides the introduction of a single European Copyright Title that would directly and uniformly apply ${ }^{93}$, the draft report suggests adapting the exceptions and limitations contained in the InfoSoc Directive to the changed technical demands and, in addition, render them uniformly applicable in every Member State. ${ }^{94}$ Whether there are less invasive measures than legal unification and whether further competences need to be conferred to the European level regarding the InfoSoc Directive can be left open herein, since considerations on regulatory coherence have to involve the whole acquis communitaire of European copyright law and should be embedded in the context of the prospective "Digital Single Market", which would widely exceed the scope of this contribution..$^{95}$

51 Following the limitation proposed in Art 5.5 European Copyright Code and the common law model of fair use ${ }^{96}$, Reda proposed to have an open norm "introducing flexibility in the interpretation of exceptions and limitations in certain special cases" in accordance with the "three-step test" and hence seeking to break up the exhaustive list of exceptions laid down in the InfoSoc Directive. ${ }^{97}$ The realization of such a norm would, however, amount to a paradigm change in European copyright law doctrine, which so far considers the use of publicly available information and knowledge as an exception, but not as a right in itself (Kuhlen, 2015).

Though this proposal appears to be controversial at first sight, the new digital environment requires a certain adaption and rethinking in terms of copyright law. In the context of digital heritagization, copyright law in its actual shape often interferes with attempts to digitize and preserve the intellectual and creative past and presence for future generations (Lessig, 2008: 261). Thereby, the purpose of copyright law is not constrained to the creation of private property rights, but it primarily seeks to foster 
cultural and intellectual progress of public interest (Gillespie, 2007: 22). In order to balance all interests involved enhanced flexibility and the interpretation of personal use in the sense of "public right" rather than something of exceptional character could help to reach this goal. Furthermore, this perception would correspond to the growing expectations and needs for information in the digital society (Gladney, $2007: 251$ ). The draft report gives new impetus to the debate on the modernization of copyright legislation (Kuhlen, 2015), but whether the proposal set a new course, only the future can tell. However, one has to consider that initiatives seeking to prevent drifting apart of law and technology cannot be confined to the regulatory level or legal technicalities. Politics, society and each individual equally play an important role for the prospective developments. Hence, the development of an understanding on the individual level for both utilization of resources and cultural participation on the one hand and balancing of public interests and creators' rights on the other hand will form a decisive precondition for the success of this endeavor. Thereby, the involvement of private actors which might fulfill a gatekeeper function and thus support knowledge and information monopolies in the context of digital heritagization will constitute an additional challenge in this regard.

\section{BIBLIOGRAPHY}

BIELER Brigitte (2015). "'Bibliothekslieferdienst" - Bundesgericht vom 28. November 2014”, sic! Zeitschrift für Immaterialgüter, Informations- und Wettbewerbsrecht, 3, pp.155-164.

CLAY Christopher (2015, January 19). "Neuer Bericht des Europaparlaments: Urheberrecht nicht für das digitale Zeitalter gerüstet”, https://juliareda.eu/2015/01/presseaussendung-bericht-euurheberrecht/, accessed 14 April 2015, 13.34.

DARTNELl Lewis (2015, February 16). "The digital black hole: will it delete your memories?", The Guardian, http://www.theguardian.com/technology/2015/feb/16/digital-black-hole-deletememories-information-lost-google-vint-cerf, accessed 14 April 2015, 11.07.

DNES Antony W. (2013). “Should the UK move to a Fair-Use Copyright Exception?", International Review of Intellectual Property and Competition Law, 44 (4), pp. 418-444.

European COMmission, Commission President Jean-Claude Juncker (2014). "Mission letter to Commissioner Oettinger", http://ec.europa.eu/commission/sites/cwt/files/commissioner

mission_letters/oettinger_en.pdf, accessed 8 April 2015, 10.43.

EUROPEAN COMMISSION (2009). “Creative Content in a European Digital Single market: Challenges for the Future”, http://ec.europa.eu/internal_market/consultations/docs/2009/content_online/

reflection_paper\%20web_en.pdf, accessed 15 April 2015, 14.30 .

EUROPEAN COMMISSION (2008). “Green Paper of 16 July 2008 on Copyright in the Knowledge Economy”, COM (2008) 466 final. 
FEDERAL OFFICE OF CULTURE (2008). “Memopolitik”, http://www.bak.admin.ch/kulturerbe/04405/?

lang=de, accessed 30 April 2015, 13.45.

FISCHER Oliver (2014). Perspektiven für ein Europäisches Urheberrecht, Baden-Baden, Stämpfli.

FISCHMAN AFORI Orit (2013). “The Battle Over Public E-Libraries - Taking Stock and Moving Ahead", International Review of Intellectual Property and Competition Law, 44 (4), pp. 392-417.

FOUNDATION FOR INFORMATION POLICY RESEARCH (2003). "Implementing the EU Copyright Directive", http://www.fipr.org/copyright/guide/eucd-guide.pdf, accessed 14 April 2015, 14.30.

GEIGER Christophe, GERVAIS Daniel \& SENFTLEBEN Martin (2013). “The Three-Step Test Revisited: How to Use the Test's Flexibility in National Copyright Law", Program on Information Justice and Intellectual Property Research Paper, no. 2013-04, pp. 1-44.

GERMAN PUBLISHERS AND BOOKSELLERS ASSOCIATION (2015, April 17). "Press release", http://

www.boersenverein.de/de/portal/Presse/158382?presse_id=956354, accessed 21 April 2015, 14.58 .

GILLESPIE Tarleton (2007). Wired Shut: copyright and the shape of digital culture, Cambridge / Massachusetts, The MIT Press.

GLADNEY Henry M. (2007). Preserving Digital Information, Berlin/Heidelberg, Springer.

GOWERS Andrew (2006). “Gower Review of Intellectual Property”, https://www.gov.uk/ government/uploads/system/uploads/attachment_data/file/228849/0118404830.pdf, accessed 30 April 2015, 17.28 .

HÄYRINEN Ari (2012). Open Sourcing Digital Heritage - Digital Surrogates, Museums and Knowledge Management in the Age of Open Networks, Jyväskylä, University of Jyväskylä.

JANI Ole (2014). "EuGH: Urheberrecht: Anforderungen an zulässige elektronische Arbeitsplätze”, Europäische Zeitschrift für Wirtschaftsrecht, pp. 875-880.

KUHLEN Rainer (2015, January 21). "Kopernikanische Wende in der EU-Urheberrechtsdebatte? Die Politik in Deutschland sollte das nutzen”, https://netzpolitik.org/2015/kopernikanische-wendein-der-eu-urheberrechtsdebatte-die-politik-in-deutschland-sollte-das-nutzen/, accessed 8 April $2015,9.32$

KUHLEN Rainer (2013). “Copyright Issues in the European Union - Towards a sciences- and education-friendly copyright”, http://www.kuhlen.name/MATERIALIEN/Publikationen2013/RKcopyright-issues-in-the-EU-submitted-preprint05032013-PDF.pdf, accessed 14 April 2015, 11.22.

LEGRAND Pierre (1997). “The impossibility of 'Legal Transplants”, Maastricht Journal of European and Comparative Law, 4, pp. 111-124.

LESSIG Lawrence (2008). Remix: Making art and commerce thrive in the hybrid economy, London, Bloomsbury Publishing.

MÜLLER Barbara K. \& OERTLI Reinhard (2006). Kommentar zum Urheberrechtsgesetz, Bern, Stämpfli.

NIEDOSTADEK André (2014, September 11). "EuGH ebnet Weg für elektronische Leseplätze - Papier war gestern", Legal Tribune Online, http://www.lto.de/recht/hintergruende/h/eugh-urteilc-117-13-elektronische-leseplaetze-bibliotheken-urheberrecht/, accessed 14 April 2015, 12.50. NOBEL Peter \& WEBER Rolf H. (2007). Medienrecht, $3^{\text {rd }}$ ed., Bern, Schulthess. 
OKEDIJI Ruth L. (2006). “The international copyright system: Limitations, Exceptions and Public Interest Considerations for Developing Countries”, ICTSD Issue Paper No. 15.

ÖRÜCÜ Esin (2002). “Law as Transposition”, The International and Comparative Law Quaterly, 51 (2), pp. 205-223.

PALM Jonas (2005). “The Digital Black Hole”, http://www.tape-online.net/docs/

Palm_Black_Hole.pdf, accessed 14 April 2015, 13.56.

PEIFER Karl-Nikolaus (2015). “EuGH: Bereitstellung digitaliserter Werke an Universitätsbibliotheken“, Lindenmaier-Möhring - Kommentierte BGH-Rechtsprechung, 1, 365446.

PURDAY Jonathan (2010). “Intellectual Property Issues and Europeana, Europe’s Digital Library, Museum and Archive", Legal Information Management, 10 (3), pp. 174-180.

RENDAS Tito (2015). "Destereotyping the Copyright Wars: The "fair use vs. closed list" debate in the EU”, SSRN Working Paper Series, http://ssrn.com/abstract=2657482, accessed 28 September 2015, 11.01 .

SÁNCHEZ-CARRETERO Cristina (2013). "Significance and social value of Cultural Heritage: Analyzing the fractures of Heritage”, pp. 387-392, in Rogerio-Candelera Miguel-Angel, Lazzari Massimo \& Cano Emilio (eds.), Science and Technology for the Conservation of Cultural Heritage, London, CRC Press.

SHEPPARD Tony (2012). "Is a New Legal Framework Required for Digital Preservation or Will Policy Do?”, http://www.unesco.org/new/fileadmin/MULTIMEDIA/HQ/CI/CI/pdf/mow/ VC_Sheppard_27_C_1330.pdf, accessed 14 April 2015, 14.27.

SPACEK Dirk (2010). “Das Google Book Settlement”, sic! - Zeitschrift für Immaterialgüter, Informationsund Wettbewerbsrecht, pp. 196-208.

VASELLA David (2014, December 28). “4A_295/2014: Dokumentenlieferdienst der ETH“, swissblawg, http://www.swissblawg.ch/2014/12/4a2952014-dokumentenlieferdienst-der.html, accessed 12.03.15, 16.42 .

WIEBE Andreas \& MÜLLER Bernhard (2015). “Die Zulässigkeit elektronischer Arbeitsplätze in Bibliotheken”, Neue Juristische Wochenschrift, 11, pp. 741-744.

XALABARDER Raquel (2014). “Google Books and Fair use: A Tale of Two Copyrights?”, Journal of Intellectual Property, Information Technology and Electronic Commerce Law, 5, pp. 53-59.

ZWEIGERT Konrad \& KÖTZ Hein (1998). Introduction to Comparative Law, $3^{\text {rd }}$ ed., Oxford, Clarendon Press.

\section{Materials}

Orphan Works Directive. Directive 2012/28/EU of the European Parliament and of the Council of 25 October 2012 on certain permitted uses of orphan works, 2012 O.J. L 299/5.

InfoSoc Directive. Directive 2001/29/EC of the European Parliament and of the Council of 22 May 2001 on the harmonisation of certain aspects of copyright and related rights in the information society, 2001 O.J. L 167/10.

Draft Report 2014/2256 (INI) of 14 January 2015.

Copyright Act, CopA. Swiss Federal Act on Copyright and Related Rights of 9 October 1992, SR 231.1. 
UNESCO, Charter on the Preservation of Digital Heritage, 2003 available at http:// portal.unesco.org/en/ev.php-URL_ID=17721\&URL_DO=DO_TOPIC\&URL_SECTION=201.html, accessed 30 April 2015, 17.11 .

\section{Case Law}

COURT OF JUSTICE OF THE EUROPEAN UNION (CJEU). Technische Universität Darmstadt $v$ Eugen Ulmer KG, Case C-117/13, [2014] E.C.R. I

(delivered 11 September 2014). COURT OF JUSTICE OF THE EUROPEAN UNION (CJEU). Opinion of Advocate General Jääskinen, Technische Universität Darmstadt v Eugen Ulmer KG, Case C-117/13, [2014] E.C.R. I_--- (delivered 11 September 2014).

GERMAN FEDERAL SUPREME COURT, judgment issued on 16 April 2015 - I ZR 69/11.

SWISS FEDERAL TRIBUNAL (SFT), judgment 4A_295/2014 dated 28 November 2014.

UNITED STATES DISTRICT COURT FOR THE SOUTHERN DISTRICT OF NEW YORK (S.D.N.Y.), The Authors Guild, Inc. v. Google, Inc., No. 05 CV 8136, 14 November 2013.

\section{NOTES}

1. Cf. UNESCO, Art. 1(2) for examples of such materials.

2. UNESCO, Art. 1(1)-(3).

3. UNESCO, Art. 2(1), (2).

4. Cf. Fischman Afori, 2013: 395.

5. UNESCO, Art. 3(2).

6. Cf. Sánchez-Carretero, 2013: 388 et seq., regarding the demarcation of "heritagization", "patrimonialización" and "patrimonialisation".

7. European Commission, 2008: 8.

8. Cf. the portal e-rara.ch (portal for historical prints), the platform e-manuscripta.ch (platform for handwritten sources) or the DigiCenter of the ETH Zurich.

9. For further details see below $4 / \mathrm{c} /$ iii.

10. Cf. http://arquivo.pt/

11. Cf. https://archive.org/

12. Dartnell, 2015: 1 et seq.; Cf. Palm, 2005, who compares digitization projects and the related digital black holes with the life cycle of a star.

13. Cf. Zweigert \& Kötz, 1998: 63 et seq., who distinguish, based on geographical-legal criteria, the Romanistic, Germanic, Nordic, Socialist, Islamic, Anglo-Saxon, Far Eastern and Hindu „legal families".

14. The "three-step test", which has been introduced on the basis of international law, serves as a general guideline and flexible framework for the adoption of limitations and exceptions to the exclusive rights of authors under copyright law; Cf. Geiger/Gervais/Senftleben, 2013: 4, 9 et seq.

15. The "three-step test" was also incorporated in Art. 5(5) InfoSoc Directive.

16. Cf. Art. 10(2)(a) CopA.

17. Cf. Art. 19 CopA.

18. Technische Universität Darmstadt, [2009] E.C.R. I_-- (delivered 11 September 2014), para. 37; European Commission, 2008, 9.

19. Cf. European Commission, 2008: 8; the InfoSoc Directive however clarifies in deliberation 40, that the online-delivery of protected works is not comprised by these exceptions. 
20. One could refer in this context to the famous books of Sigmund Freud or Le Petit Prince of Antoine de Saint-Exupéry, whose copyright protection recently expired.

21. KG, acronym of the German Kommanditgesellschaft, means „limited commercial partnership“.

22. Opinion of AG Jääskinen, Technische Universität Darmstadt, [2009] E.C.R. I_-- (delivered 11 September 2014), paras. 12 et seq.

23. Technische Universität Darmstadt, [2009] E.C.R. I_-- (delivered 11 September 2014), paras. 22 et seq.

24. Technische Universität Darmstadt, [2009] E.C.R. I_-- (delivered 11 September 2014), para. 40; Opinion of AG Jääskinen, Technische Universität Darmstadt, [2009] E.C.R. I_--- (delivered 11 September 2014), para. 31.

25. Technische Universität Darmstadt, [2009] E.C.R. I_-- (delivered 11 September 2014), para. 43; Opinion of AG Jääskinen, Technische Universität Darmstadt, [2009] E.C.R. I_-- (delivered 11 September 2014), para. 34; Cf. Wiebe/Müller, 2015, 745 with regard to the deviating appreciation of the German Federal Supreme Court.

26. Technische Universität Darmstadt, [2009] E.C.R. I__-- (delivered 11 September 2014), para. 44.; Cf. Opinion of AG Jääskinen, Technische Universität Darmstadt, [2009] E.C.R. I_-- (delivered 11 September 2014), paras. 34 et seq., according to whom the right to digitize could be derived from Art. 5(3)(n) as well as Art. 5(2)(c) InfoSoc Directive, whereas the Court read both provision in conjunction with each other.

27. Technische Universität Darmstadt, [2009] E.C.R. I_-- (delivered 11 September 2014), paras. 45 et seq.; Opinion of AG Jääskinen, Technische Universität Darmstadt, [2009] E.C.R. I_-- (delivered 11 September 2014), para. 38.

28. Technische Universität Darmstadt, [2009] E.C.R. I_-- (delivered 11 September 2014), para. 47.

29. Technische Universität Darmstadt, [2009] E.C.R. I_-- (delivered 11 September 2014), paras. 22 et seq.

30. Cf. Niedostadek, 2014; Technische Universität Darmstadt, [2009] E.C.R. I_-- (delivered 11 September 2014), paras. 26, 30, 35.

31. Technische Universität Darmstadt, [2009] E.C.R. I_-- (delivered 11 September 2014), paras. 22, 50.

32. Technische Universität Darmstadt, [2009] E.C.R. I_-- (delivered 11 September 2014), paras. 52 et seq.

33. Technische Universität Darmstadt, [2009] E.C.R. I_-- (delivered 11 September 2014), paras. 55, 57; Cf. Opinion of AG Jääskinen, Technische Universität Darmstadt, [2009] E.C.R. I_-- (delivered 11 September 2014), para. 57, according to whom paper printouts could also be subsumed under Art. 5(2)(c) InfoSoc Directive and insofar deviates from the Court's findings.

34. Technische Universität Darmstadt, [2009] E.C.R. I_-- (delivered 11 September 2014), para. 56

35. Cf. InfoSoc Directive, recital 5 et seq.; Niedostadek, 2014.

36. Cf. Opinion of AG Jääskinen, Technische Universität Darmstadt, [2009] E.C.R. I_-- (delivered 11 September 2014), paras. 36 et seq.

37. Opinion of AG Jääskinen, Technische Universität Darmstadt, [2009] E.C.R. I_-- (delivered 11 September 2014), paras. 34, 35.

38. Cf. UNESCO, Art. 7 with regard to such selection principles.

39. Cf. Jani, 2014: 873 with regard to the admissibility of subsequent acts of reproduction under German law.

40. Cf. judgment of the German Federal Supreme Court issued on 16 April 2015 - I ZR 69/11.

41. German Publishers and Booksellers Association, 2015.

42. SFT judgment 4A_295/2014, A.b.

43. SFT judgment 4A_295/2014, B. 
44. Cf. Nobel \& Weber, 2007: 580 et seq., according to whom digitization measures can affect the general clause of Art. 10(1) CopA as well as the different forms of use pursuant to Art. 10(2) CopA.

45. SFT judgment 4A_295/2014, E. 3.5.2, 3.5.3.

46. SFT judgment 4A_295/2014, E. 3.5.1.

47. SFT judgment 4A_295/2014, E. 3.5.2.

48. SFT 133 III 473 et seq., E. 4.3.

49. Bieler, 2015: 162; SFT judgment 4A_295/2014, E. 3.4.1.

50. SFT judgment 4A_295/2014, E. 3.2.

51. SFT judgment 4A_295/2014, E. 3.6.1.

52. SFT judgment 4A_295/2014, E. 3.6.5; Vasella, 2014.

53. SFT judgment 4A_295/2014, E. 3.6.5.

54. Bieler, 2015: 163.

55. SFT judgment 4A_295/2014, E. 3.6.6

56. SFT judgment 4A_295/2014, E. 3.4.1.

57. SFT judgment 4A_295/2014, E. 3.4.2.

58. SFT judgment 4A_295/2014, E. 3.4.3.

59. SFT judgment 4A_295/2014, E. 3.4.4.

60. Cf. SFT judgment 4A_295/2014, E. 3.4.1; Cf. Bieler, 2015: 162.

61. The Authors Guild, Inc. v. Google, Inc., 1, 4 et seq.; Cf. Xalabarder, 2014: 53.

62. The Authors Guild, Inc. v. Google, Inc., 15; Cf. Xalabarder, 2014: 53.

63. Cf. Xalabarder, 2014: 53; The Authors Guild, Inc. v. Google, Inc., 1, 6.

64. Cf. Xalabarder, 2014: 54; The settlement agreement was not approved, since "it would simply go too far" and involve inter alia legal issue with regard to orphan works and out-of-print works which would have primarily remained in the hands of Google; Cf. Spacek, 2010: 196 et seq., for a more comprehensive overview.

65. The Authors Guild, Inc. v. Google, Inc., 1 et seq.

66. The Authors Guild, Inc. v. Google, Inc., 16.

67. Cf. 17 U.S.C. § 107(1).

68. The Authors Guild, Inc. v. Google, Inc., 19; Xalabarder, 2014: 55.

69. The Authors Guild, Inc. v. Google, Inc., 19.

70. The Authors Guild, Inc. v. Google, Inc., 20.

71. The Authors Guild, Inc. v. Google, Inc., 20 et seq.

72. The Authors Guild, Inc. v. Google, Inc., 21.

73. The Authors Guild, Inc. v. Google, Inc., 22; According to the S.D.N.Y., the Google Books project would serve "important educational purposes"; Cf. Xalabarder, 2014: 55.

74. Cf. 17 U.S.C. § 107(2).

75. The Authors Guild, Inc. v. Google, Inc., 22 et seq.

76. Cf. 17 U.S.C. § 107(3).

77. The Authors Guild, Inc. v. Google, Inc., 23 et seq.

78. § 107 U.S.C. § 107(4)

79. The Authors Guild, Inc. v. Google, Inc., 24.

80. The Authors Guild, Inc. v. Google, Inc., 25.

81. The Authors Guild, Inc. v. Google, Inc., 26.

82. The Authors Guild, Inc. v. Google, Inc., 26.

83. Xalabarder, 2014: 56; The Authors Guild, Inc. v. Google, Inc., 26 et seq.

84. Cf. 4./a. with regard to the conceptual approximation.

85. Kuhlen, 2013: 3, with further references.

86. Rendas, 2015 : 15 et seq. ; the lack of democratic participation is one of the big problems in this context.

87. Cf. Okediji : 2006, 27 
88. Cf. Spacek, 2010: 198 with regard to the role of orphan works for the amended settlement agreement in the context of Google Books.

89. Art. 6(1)(b) Orphan Works Directive; Cf. Fischman Afori, 2013: 396.

90. Cf. European Commission, Commission President Juncker, 2014.

91.

92. Cf. Draft Report, 1 et seq.

93. Cf. Draft Report, 5 .

94. Cf. Draft Report, 6; Kuhlen, 2015: with critical remarks.

95. Cf. European Commission, 2009: 18, which does not only consider a uniformly applicable European copyright title, but also an optional regime; Cf. Fischer, 2014: 179 et seq.

96. Breda especially referred to the well-known term of "transformative use”, which was of importance for the first factor of assessment of fair use in the Google Books case before the S.D.N.Y.

97. Cf. Draft Report, 6 .

\section{ABSTRACTS}

Due to the development of information and communication technologies as well as the influence of the Internet, life and work of the contemporary society take increasingly place in virtual form and the approach towards knowledge and heritage fundamentally altered. The remarkable sign of this continuous process is the emergence of Digital Heritage, understood as the accumulation of computer-based, valuable materials, which constitutes a digital reflection of societal developments. Different "heritage institutions" from the public sector, such as archives, libraries, museums, but also private undertakings became involved in the related process of Digital Heritagization encompassing cultural, scientific and administrative resources. The objective aimed for is the preservation of the named resources in order to enable future generations to access the collective memory of our society by means of electronic records. Since the digitization of analogue resources and the utilization of born-digital content presupposes inter alia the reproduction and duplication of the content in question, the field of intellectual property law gains particular interest. Thereby, the discussion on the national and international level is characterized by the heterogeneous and partly restrictive legal framework. The contribution takes this new environment as opportunity to approach the legal framework of civil law as well as common law jurisdictions related to digital heritage from a copyright law perspective, with particular reference to the legal exemptions and fair dealings doctrine. In order to emphasize the high practical impact of the issue at stake, recent judgments of the ECJ, the Swiss Federal Tribunal and the S.D.N.Y. (Google Books Case) assessing the admissibility of the digitalization and related aspects are considered and critically evaluated. On that basis, the future need of legislative measures in order to balance personal proprietary rights and public interests is discussed.

En raison du développement des technologies de l'information et de la communication et de l'influence d'Internet, la vie et le travail de notre société contemporaine s'inscrit de plus en plus dans des formes virtuelles et modifie fondamentalement le rapport au savoir et au patrimoine. Le signe le plus notable de ce processus continu est l'émergence du patrimoine numérique, entendu comme l'accumulation sur support informatique de matériel considéré comme signifiant, qui 
constitue le reflet numérique des développements sociétaux. Différentes institutions patrimoniales du secteur public, comme le monde des archives, bibliothèques, musées mais aussi des initiatives privées s'investissent dans le processus de patrimonialisation numérique qui y est associé et englobe des ressources culturelles, scientifiques et administratives. L'enjeu sous-jacent est la préservation de ces ressources afin de permettre aux générations futures d'accéder à la mémoire collective de nos sociétés par le biais d'enregistrements électroniques. Puisque la numérisation de ressources analogiques et l'utilisation de contenus nativement numériques présuppose, entre autres, leur reproduction et duplication, le droit de propriété intellectuelle est pertinent dans ce contexte. Par ailleurs, les discussions nationales et internationales sont caractérisées par un cadre juridique hétérogène et partiellement restrictif. Cet article considère la patrimonialisation numérique à l'aune du régime du droit d'auteur, en se référant tout particulièrement aux exceptions légales et la doctrine de l' "usage raisonnable ». Des jugements récents émis par la Cour de justice européenne, le tribunal fédéral suisse et le tribunal du district Sud de New York (le célèbre « Google Books Case »), portant sur l'admissibilité de la numérisation et aspects corrélés, seront examinés. Sur cette base, l'article examine enfin les besoins futurs de mesures législatives visant à équilibrer les droits de propriété personnels et l'intérêt public.

\section{INDEX}

Mots-clés: droit d'auteur, patrimoine numérique, cas « Google Books », propriété intellectuelle, UNESCO

Keywords: copyright law, digital heritage, Google Books case, intellectual property, UNESCO

\section{AUTHORS}

\section{ROLF H. WEBER}

University of Zurich, Center for Information Technology, Society and Law (ITSL)

\section{LENNART CHROBAK}

University of Zurich 